\title{
Consonant Deletion in the Speech of English-Platoid Bilinguals
}

\author{
Unubi, Sunday Abraham \\ Department of English and Literary Studies, Kogi State University, \\ PMB 1008 Anyigba, Nigeria \\ ununbi4u@gmail.com
}

\begin{abstract}
This paper, which examines consonant deletion in the speech of English-Platoid bilinguals, is in the domain of articulatory phonetics. When English words end in two or three consonants, speakers of English who are native speakers of Platoid languages usually delete consonants word finally during articulation. This has been of deep interest to the researcher, and therefore decides to investigate the phenomenon that leads to this incidence as a way of proffering a linguistic explanation to it. To do this, a total of twenty-two sentences containing words that end in two or three consonants were used as data elicitation technique from some English-Platoid bilinguals. These words were noted by the researcher during informal daily conversations at different occasions. The words whose consonants got deleted at the word final position were transcribed phonetically for purposes of clarity. The second part of the data constitutes the elicitation of six words of common nouns each from ten indigenous Platoid languages. Since the focus is on consonant deletion, few consonant systems of these languages were also presented. This is so done with a view to discovering whether there is evidence of consonant cluster in those languages or not, especially at word final position in order for the researcher to pin down the factor responsible for the deletion. From there, the study concludes that there is no evidence of consonant cluster at word-final positions in Platoid languages, and where it does, it only exists as digraph orthographically, as in: shīk-bīsh 'sin', kàt-dang 'if' (Mwaghavul); kámbọng 'cocoyam' (Ron); ishọsh 'honey bee', nànámàng 'girls' (Afizere); ikpáng 'plate', ǹding 'water' (Tarok), etc.
\end{abstract}

Key words: Platoid, consonant deletion, bilingual.

\section{Introduction}

Throughout the researcher's time of sojourn in Jos, the Plateau State capital (for both undergraduate and graduate studies), this incidence of consonant deletion has been a great drawer of my attention. This study, which is on consonant deletion in the speech of English-Platoid bilinguals, belongs to the domain of articulatory phonetics, and it is embarked upon to carefully scrutinise the circumstance that necessitates the deletion.

The Platoid of north-central Nigeria is one of the major branches of the New Benue-Congo family. Blench (2008:1) reports that among the many language groups represented in Nigeria, one of the largest and most complex is the Platoid languages, representing some 50-120 languages, depending on how inclusive the term is taken to be. The Platoid is believed to be a larger and highly complex branch, extending across the northern boundary of the Benue-Congo and subdividing into Kainji, which includes languages such as Kambari, spoken near Lake Kainji, and Central Platoid, which in turn divides into 
Unubi, Sunday Abraham; Consonant Deletion in the Speech of English-Platoid Bilinguals, Advances in Image and Video Processing, Volume 7 No 1, February (2019); pp: 19-33

Plateau, containing many of the small languages spoken around Jos, and in Southern part of Kaduna State, Tarokoid, including Tarok and other languages east of Jos (Williamson, 1987:18 \& Ogbulogo 2013:12). Blench (2008:2) further notes that Tarokoid is part of Plateau (or Platoid), albeit a primary branching and similarities with Jukunoid are due to proximity, and that membership of Tarokoid should be restricted to Tarok, Pe, Yankam and Sur (also known as Tapshin).

Linguistically, Plateau State has over forty ethno-linguistic groups but no single group is large enough to claim majority position. Some of the indigenous tribes in the State include: Afizere, Amo, Anaguta, Angas, Aten, Berom, Bogghom, Buji, Challa, Chip, Fier, Gashish, Goemai, Irigwe, Jarawa, Jukun, Kwagalak, Kwalla, Meryang, Miship, Montol, Mushere, Mupum, Mwaghavul, Ngas, Piapung, Pyem, Ron, Kulere, Tarok, Youm, etc. Each ethnic group has its own distinct language, but as with the rest of the country, English is the official language in Plateau State, although Hausa has gained acceptability as a medium of communication (http://www.informationng.com).

\section{Statement of the Research Problem}

Prior to the time of this research, there has been little or no investigative study that could lead to a valid statement or conclusion on why English-Platoid bilinguals (especially indigenes of Plateau State, North-Central Nigeria) delete the last consonant sound in a cluster of consonants during speech or utterance. Could it be English-Platoid bilinguals have no consonant cluster both at the onset and coda, or they have at the onset and none at the coda or vice-versa? What reason could be advanced for the consonant deletion at the coda? This in itself is a wide knowledge gap that has been waiting to be filled. In view of this, the researcher was moved or motivated by strong inner drive as well as deep passion to carry out this study with a view to filling this knowledge gap.

\section{Literature Review}

Our review of literature here will focus mainly on the important concepts that constitute the topic or title of this research, which are consonant deletion and bilingual. Besides these, the review will include empirical works done by other language scholars over the years that are related to the current research.

\subsection{Conceptual Review}

Deletion is the art of removing something that has been written or printed. Consonant deletion, therefore, means eliminating a consonant sound in a word. In the light of this, Rippon (2017:4) states that consonant deletion takes place when one or two consonant sounds are omitted from the beginning, middle or end of words. In Akan language, Adomako (2008:32) reveals that deletion of consonants usually occurs in two main ways, mostly in the word-final and rarely in the word-medial positions. Either, the C1 of the cluster is deleted or the C2 of the cluster is deleted. Similarly, Rashidi \& Shokrollahi (2010:138) observe from their study on the Shirazi dialect of Persian that glottal consonants /h/ and /?/ are deleted in all phonetically weak positions: coda-position (word-finally), intervocalic position and in clusters but they are retained word-initially. In an attempt to explain the concept of deletion, Ovu (2013:10) points out that pronouncing the words such as psychology, pseudonym, psalm, psychiatrics, psyche, etc. with the initial /p/ sound would apparently result in a deviant consonant cluster in English. This is because at the onset, English cannot allow a combination of plosive + fricative. Thus, faced by this dilemma, English speakers usually drop or delete the consonant sound /p/ while retaining that of $/ \mathrm{s} /$ in their pronunciation. At word medially and finally, he further posits that the consonant sound / $\mathrm{b} /$ is usually silent in two main areas, namely where it combines with the sound / $\mathrm{t} /$ and where it combines with that of $/ \mathrm{m} /$, as exemplified in the following words: subtle, doubt, debt, plumb, climb, dumb, tomb, bomb, etc. adding that the reason for this is the peculiarity of English phonotactics which does not allow a sequence of $/ \mathrm{mb} /$ or $/ \mathrm{bm} /$ sounds to form a cluster whether word 
initially or finally. However, considering the focus of our study, this is not the case at all with the native speakers of the Platoid languages who speak English as their L2. Their deletion of consonants wordfinally in speech is never attributable to the phonotactics of English. This, indeed, is the driving force behind this study, that is, to lay bare before the reader what actually is responsible for this phenomenon during articulation.

According to Crystal (1991:53), the general sense of the term bilingual refers to a person who can speak two languages. However, this is dependent on several factors. Defining who a bilingual is reflects assumptions about the degree of proficiency people must achieve before they qualify as bilinguals (whether comparable to a monolingual native-speaker, or something less than this, even to the extent of minimal knowledge of a second language). Similarly, Bloomfield (1933) as cited in Liddicoat (1991:2) defines a bilingual as one who has 'native-like' control of two languages. But this definition excludes many people who speak more than one language but do not have 'native-like' control of one or both of their languages. In addition, Franson (2011:1) says that the term bilingual is used to describe a learner who uses two or more languages to communicate. However, defining who a bilingual is ranges from a minimal proficiency in two languages, to an advanced level of proficiency which allows the speaker to function and appear as a native-like speaker of two languages; a person may describe himself as a bilingual but may mean only the ability to converse and communicate orally; others may be proficient in reading in two or more languages; a person may be a bilingual by virtue of having grown up learning and using two languages simultaneously, or s/he may become a bilingual by learning a second language sometime after his/her first language. So, to be a bilingual means different things to different people. Irrespective of the difficulty in defining who a bilingual is (or factors determining who a bilingual is), our focus in this research is to investigate how native speakers of the Platoid languages (within Jos, Plateau State) who also speak English as a second language, delete consonants, especially at word-final positions during articulation.

\subsection{Empirical Review}

Empirically, studies on a subject such as this are not very common in Nigeria, and perhaps, other parts of the world. However, few related researches have been conducted by some language scholars both home and abroad, even though they are not linked to a particular group of people like ours. They are as follows:

Davidson (2004) embarked on research entitled Schwa Elision in Fast Speech: Segmental Deletion or Gestural Overlap? Through intuition, the researcher observed phonological analyses attributing schwa elision to across-the-board segmental deletion, and phonetic accounts proposing that elision, being characterised as gestural overlap have been restricted to very few sequence types. In the method, 28 different [\#CəC-] sequences were examined and 9 participants ( 6 males and 3 females) were used to define appropriate acoustic criteria for elision, to establish whether elision is a deletion process or the endpoint of a continuum of increasing overlap, and to discover whether elision rates vary for individual speakers. The result of the study revealed that the acoustic patterns for elision are consistent with an overlap account. Individual speakers differ as to whether they increase elision only at faster speech rates, or elide regardless of rate.

Furthermore, Adomako (2008) conducted a research titled Vowel Epenthesis and Consonant Deletion in Loanwords: A Study of Akan. The aim of this study was to shed light on the loanword adoption phenomenon in Akan, a majority language spoken in the West African country of Ghana. Foreign words with sequences of obstruents as in $/ \mathrm{st} /, / \mathrm{sp} /, / \mathrm{pl} /, / \mathrm{sk} /$, etc. and word-final obstruents adopted into the language have to go through some repair processes to conform to the structural well-formedness 
Unubi, Sunday Abraham; Consonant Deletion in the Speech of English-Platoid Bilinguals, Advances in Image and Video Processing, Volume 7 No 1, February (2019); pp: 19-33

requirement in the native grammar. The two main repair strategies that apply to these illicit foreign words include vowel epenthesis and consonant deletion. As for the methodology, the database, which served as the basis of this study, was a collection of loanword corpus from the two of Akan dialects: Fante and Twi. An initial set of loanword corpus of over 200 words was collected on the field from two sets of informants: the monolingual and the bilingual speakers at two different locations. The monolingual speakers are predominantly illiterates, i.e. they do not have any formal education, while the bilingual speakers, on the other hand, are either literates or semi-literates, i.e. the members constituting this group have, at least, basic formal education. The finding of the research showed that differences exist between the two dialects, and that they have more in common than they differ in terms of how they adopt foreign words.

Moreover, Gerlach (2010) undertook a study titled The Acquisition of Consonant Feature Sequences: Harmony, Metathesis and Deletion Patterns in Phonological Development. The researcher, in this research, examines three processes affecting consonants in child speech: harmony (long-distance assimilation) involving major place features as in coat [kovk]; long-distance metathesis as in cup [p $\wedge$ ]; and initial consonant deletion as in fish [I]]. These processes are unattested in adult phonology, leading to proposals for child-specific constraints. Initial consonant deletion in particular, is a little-understood phenomenon thought to be idiosyncratic but initial consonant deletion as reported in eight languages reveals systematic deletion patterns affecting continuants and sequences of different consonants. From the methodology, the data used displayed evidence for both constraint demotion and promotion in learning, as well as distinct roles for two types of faithfulness constraints: one mandates the preservation of non-default features that are specified in the underlying representation, while the other evaluates identity of a correspondent segment to any non-default feature associated with a segment.

Lastly, Ovu (2015) carried out a study titled Consonant Deletion in English: Phonotactic Explications and Implications for Teaching Spelling in an ESL Situation. The study considers consonant deletion as one of the major contributors to the irregularities in the spelling system of English, and accounts for a great number of pronunciation errors committed by the L2 users of English. The main thrust of this paper is to show that consonant deletion is not often haphazardly done in English but rather it is systematic and governed by some rules which obtain from the phonemic system of the language. These rules are known as phonotactic rules, and their non-observance would not only result in erroneous pronunciation but could portray a speaker as being careless and at times incompetent in using the language - a situation that may be very embarrassing. Focusing on the phonotactic basis of consonant deletion, the paper attempted to bridge this yawning gap by providing some insights into some simple but effective ways of improving the ESL users' spelling ability and boosting their confidence when communicating with native speakers of English or before an international audience.

\section{Theoretical Framework}

This research is hinged on Firth's theory of descriptive linguistics of 1951 . Originally, the term descriptive was coined to express the distinction between historical or comparative linguistics, which dominated much of 19th century linguistics, and the emerging structuralist paradigm with its emphasis on the notion of a synchronic system. Firth, as echoed by Love (1986:31) maintains that the business of linguistics is to describe language. She further reports that Firth takes linguistics to be primarily concerned with the speech-events themselves, and dealing with speech-events will involve the systematic deployment of analytical constructs and categories, which may in practice turn out to be rather similar to the constructs and categories involved in the analysis of abstract systems underlying speech-events. In a clearer perspective, descriptive linguistics is a study of a language, its structure, 
and its rules as they are used in daily life by its speakers from all walks of life, including standard and nonstandard varieties, that is, descriptive linguistics describes the language, its structure, and the syntactic rules that govern sentence and phrase constructions. Importantly, the concept of descriptive analysis is, in principle, applicable to any set of data, provided that these data represent the actual usage of a language under study at a given time in a given speech community.

From the foregoing, it is obvious that descriptive theory perfectly fits into this study. This is because in this research, we will describe vividly how native speakers of Platoid languages who speak English as L2 delete consonants word-finally during articulation. And of course, such description can never be complete, valid and reliable without the use of data. Data is considered as a tool with which linguists analyse or describe any language or its use by a particular speech community scientifically with a view to arriving at valid conclusions.

\section{Methodology}

This study, which investigates consonant deletion in the speech of English-Platoid bilinguals, is a qualitative one. Amenorvi (2011:62) quotes Shank (2002) as saying that a qualitative study can be defined as a form of systematic empirical enquiry into meaning. Systematic here means that the study should be well planned and organised, and empirical here means that such an enquiry should be grounded in the world of experience. In line with this, the researcher has experientially witnessed how native speakers of Platoid languages who speak English as second language do delete consonants at word-final positions during articulation, an incidence which informed the present study. Furthermore, as cited in Amenorvi (2011:62), Fraenkel and Norman (2002) as well as Reinard (1998) outline the major characteristics of a qualitative study, which include: "qualitative data, flexible design, naturalistic enquiry, personal contact and insight, inductive analysis and holistic perspective". In view of this, a total of twenty-two sentences containing words whose word-final consonants were deleted by native speakers of Platoid languages, who speak English as second language was used as the first part of data collected for this study. For purposes of clarity and specificity, the words whose final consonants were deleted were transcribed phonetically. In addition, six words each were elicited from ten Platoid indigenous languages along with few of their consonant systems because some of the languages are yet to be developed. And that forms the second part of the data. This is used as a tool through which the researcher is enabled to pin down the factor responsible for this phenomenon among EnglishPlatoid bilinguals. All these were done using personal contact, informal and phone conversations technique, which were carefully noted as well as personal intuition of the researcher, having dwelt among them for about eight years.

\section{Presentation of Data, Analysis/Discussion}

As mentioned earlier on in our methodology, a total of twenty-two sentences containing words whose word-final consonants were deleted by English-Platoid bilinguals is used as the first part of data collected for this study, while six words each were elicited from ten Platoid indigenous languages, and this forms the second part of the data. This is done with the sole aim of boosting our analysis and to make us reach a valid and cogent conclusion. We therefore present the data as follows:

(A) 1. The studen is sick. [stju:dan] instead of /stju:dənt/.

2. Please do not stop my movemen. [mu:v.man] instead of /mu:v.mənt/.

3. God always keeps covenan. [k^v.ən.ən] instead of /k^v.ən.ənt/. 
4. Our governmen has failed. [g^van.men] instead of /g^vən.ment/.

5. Let us go and plan cassava. [pla:n] instead of /pla:nt/.

6. Please repen of your sin today. [ripen] instead of /ripent/.

7. I had lef before you came. [lef] instead of /left/.

8. INEC is planning to shif the 2019 general elections. [Jff] instead of /Jrft/.

9. The shaf of his car had been removed. [Ja:f] instead of /Ja:ft/.

10. What is my faul in this matter? [fo:l] instead of /fo:lt/.

11. Please let the secon person come in. [sekan] instead of /sekənd/.

12. It is very col in Jos at the moment. [kav/] instead of /kəold/.

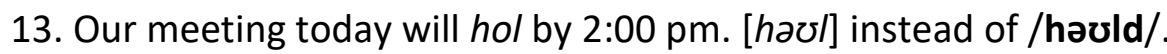

14. Please fol the bed sheet gently. [fav/] instead of /fəold/.

15. The conduc of the general elections was peaceful. [kond^k] instead of /knnd $\mathbf{k t} /$.

16. Aspec of the Theory of Syntax. [æspek] instead of /æspekt/.

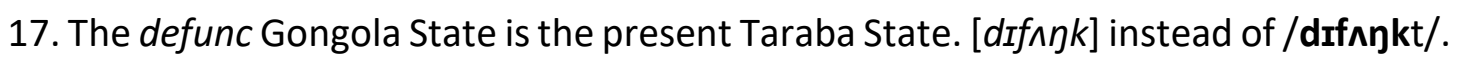

18. Adjunc means extra information. [ædろ^クk] instead of /ædъ^クkt/.

19. Always respec your elders. [rispek] instead of /rispekt/.

20. What is the cos of this handset? [kps] instead of / kbst/.

21. The ship is approaching our coas. [kəus] instead of /kəust/.

22. Please roas this maize for me. [rəos] instead of /rəust/.

\subsection{Analysis/Discussion}

Considering the above data, it is clear that the consonant deleted in 1-6 involves the alveolar plosive $/ t /$, which usually occurs when preceded by the alveolar nasal consonant $/ \mathbf{n} /$. From 7-10, the consonant deleted still remains the alveolar plosive / $\mathbf{t} /$ but this time around, the deletion occurs when it is preceded by the labiodental fricative /f/ or the alveolar lateral /I/. Then from 11-14, we can see that the deleted consonant is the alveolar plosive /d/, and it usually occurs when preceded by the alveolar nasal consonant / $\mathrm{n} /$ or the alveolar lateral /I/. Furthermore, from 15-22, the consonant involved in the deletion there is, once again, the alveolar plosive / $t /$. However, as we can see clearly, the deletion often 
takes place when it is preceded by the velar plosive $/ \mathbf{k} /$, the velar nasal $/ \mathbf{n} /$ and the alveolar fricative $/ s /$.

Furthermore, this phenomenon of consonant deletion by English-Platoid bilinguals as displayed in the above data, as a matter of fact, could affect the semantics, comprehension or intelligibility of the words concerned. This is because the words have been altered both orthographically and phonetically. Imagine an English-Platoid bilingual, who says to his interlocutor, who is a native speaker of English in a conversation, for instance: Let us go and plan cassava; INEC is planning to shif the 2019 general elections; I had lef before you came; What is my faul in this matter?; The shaf of his car had been removed; Our meeting today will hol by 2:00 pm; Please fol the bed sheet gently; What is the cos of this handset?; etc. This could get the interlocutor, who is a native speaker of English confused because the words contained in these sentences are obviously unfamiliar to him/her thereby impeding intelligibility or comprehension. As an implication then, for such a native speaker of English to get acquainted with consonant deletion by English-Platoid bilinguals, he or she needs to devote time to learn this phonological phenomenon.

\subsection{The Phonetic Factor Responsible for this incidence}

To be able to conclusively capture or pin down the phonetic factor that accounts for this phenomenon among the English-Platoid bilinguals, we present here a data (comprising mainly common nouns) elicited from ten Platoid indigenous languages as well as few of their consonant systems (few because some of the languages are yet to be written), which forms the second part of our data for this study. The words contained in the data in question are both tone-marked and transcribed phonetically for clarity on the part of the readership, as outlined below:

\section{(B) 1. Tarok Consonant Sounds \& Some Lexical items}

\begin{tabular}{|c|c|c|c|c|c|c|c|c|}
\hline $\begin{array}{l}\text { Place } \rightarrow \\
\text { Manner } \downarrow\end{array}$ & Labial & $\begin{array}{l}\text { Labio- } \\
\text { dental }\end{array}$ & Alveolar & $\begin{array}{l}\text { Palato- } \\
\text { alveola }\end{array}$ & Palatal & Velar & $\begin{array}{l}\text { Labio- } \\
\text { velar }\end{array}$ & Glottal \\
\hline Plosive & $\begin{array}{l}p \\
b\end{array}$ & & $\begin{array}{l}t \\
d\end{array}$ & & & $\begin{array}{l}k \\
g\end{array}$ & $\begin{array}{l}\text { kp } \\
\text { gb }\end{array}$ & $?$ \\
\hline Implosive & b & & d & & & & & \\
\hline Fricative & & $\begin{array}{l}f \\
v\end{array}$ & $\begin{array}{l}\mathrm{s} \\
\mathrm{z}\end{array}$ & $\begin{array}{l}5 \\
3\end{array}$ & & $\gamma$ & & h \\
\hline Affricate & & & & $\begin{array}{l}\text { t5 } \\
\text { ds }\end{array}$ & & & & \\
\hline Nasal & $\mathrm{m}$ & & $\mathrm{n}$ & & $\mathrm{n}$ & n & & \\
\hline Lateral & & & $I$ & & & & & \\
\hline Trill & & & $r$ & & & & & \\
\hline $\begin{array}{l}\text { Semi- } \\
\text { vowels }\end{array}$ & & & & & $y$ & & $\mathbf{w}$ & \\
\hline
\end{tabular}




\section{Word}
(a) Nzhi
/ $\mathrm{zzī/}$
'house'
(b) Itọk
/Itok/
'chair'
(c) lyamrì
/ījamrì/
'food'
(d) Ǹding
/ìdı̃y/
'water'
(e) Ìkpáng
/ikpán/
(f) Ákwàp
/ákwàp/

1. Mwaghavul Consonant Sounds \& Some Lexical items

\begin{tabular}{|c|c|c|c|c|c|c|c|}
\hline $\begin{array}{l}\text { Place } \rightarrow \\
\text { Manner } \downarrow\end{array}$ & Bilabial & $\begin{array}{l}\text { Labio- } \\
\text { dental }\end{array}$ & Alveolar & $\begin{array}{l}\text { Palato- } \\
\text { alveolar }\end{array}$ & Palatal & Velar & Glotal \\
\hline Plosive & $\begin{array}{l}p \\
b\end{array}$ & & $\begin{array}{l}\mathrm{t} \\
\mathrm{d}\end{array}$ & & & $\begin{array}{l}\mathrm{k} \\
\mathrm{g}\end{array}$ & $?$ \\
\hline Implosive & b & & d & & & & \\
\hline Fricative & & $\begin{array}{l}\text { f } \\
v\end{array}$ & $\begin{array}{l}5 \\
z\end{array}$ & $\begin{array}{l}\int \\
3\end{array}$ & & $\gamma$ & $\mathbf{h}$ \\
\hline Affricate & & & & $\begin{array}{l}\text { t } \\
\text { ds }\end{array}$ & & & \\
\hline Lateral & & & $I$ & & & & \\
\hline Trill & & & $r$ & & & & \\
\hline Approximant & $\mathbf{w}$ & & & & $\mathbf{Y}$ & & \\
\hline Nasal & $m$ & & $\mathrm{n}$ & & & $\eta$ & \\
\hline
\end{tabular}

Word

Gloss

(a) Làngtíng /làntín/'witness'

(b) Shikbish / /îkbīj/ 'sin'

(c) Mpúlpùl /mpúlpùl/ 'butterfly'

(d) Ǹtìsh / / ’̀̀tij/ 'snail'

(e) Dàkwat /dàkwāt/ 'male hunter'

(f) Naanfwang /nāānfwān/ 'God guides'. 


\section{Ngas Consonant Sounds \& Some Lexical items}

\begin{tabular}{|c|c|c|c|c|c|c|c|}
\hline $\begin{array}{l}\text { Place } \rightarrow \\
\text { Manner } \downarrow\end{array}$ & Bilabial & $\begin{array}{l}\text { Labio- } \\
\text { dental }\end{array}$ & Alveolar & $\begin{array}{l}\text { Palato- } \\
\text { alveolar }\end{array}$ & Palatal & Velar & Glotal \\
\hline Plosive & $\begin{array}{l}p \\
b\end{array}$ & & $\begin{array}{l}\mathrm{t} \\
\mathrm{d}\end{array}$ & & & $\begin{array}{l}\mathrm{k} \\
\mathrm{g}\end{array}$ & $?$ \\
\hline Implosive & b & & d & & & & \\
\hline Fricative & & $\begin{array}{l}f \\
v\end{array}$ & $\begin{array}{l}5 \\
z\end{array}$ & $\begin{array}{l}\int \\
3\end{array}$ & & $x$ & 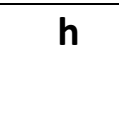 \\
\hline Affricate & & & ts & $\begin{array}{l}t \\
\text { d3 }\end{array}$ & & & \\
\hline Lateral & & & I & & & & \\
\hline Trill & & & $r$ & & & & \\
\hline Approximant & $\mathbf{w}$ & & & & y (j) & & \\
\hline Nasal & $\mathrm{m}$ & & $n$ & & & $\eta$ & \\
\hline
\end{tabular}

In addition to the individual consonant sounds, Ngas has:

(i) Palatalised consonants usually written as: $p^{y}, b^{y}, k^{y}, g^{y}, m^{y}$ and $f^{y}$;

(ii) Labialised consonants written as: $\mathrm{p}^{\mathrm{w}}, \mathrm{b}^{\mathrm{w}}, \mathrm{b}^{\mathrm{w}}, \mathrm{k}^{\mathrm{w}}, \mathrm{m}^{\mathrm{w}}, \mathrm{n}^{\mathrm{w}}, \mathrm{g}^{\mathrm{w}}, \mathrm{f}^{\mathrm{w}}, \mathrm{s}^{\mathrm{w}}, 3^{\mathrm{w}}, \mathrm{t}^{\mathrm{w}}, \mathrm{d} \mathrm{z}^{\mathrm{w}}$ and;

(iii) Pre-nasalised consonants written as: ${ }^{m} p,{ }^{m} b,{ }^{n} t,{ }^{n} d,{ }^{n} s$ and ${ }^{n} 3$.

Word
(a) Chùk
/tjòk/
'knife'
(b) Pùk
/pùk/
'soup'
(c) Nyár
/njér/
'bird'
(d) Ngón
/ngón/
'snake'
(e) Gùrm
/gùràm/
(f) Chọ̀k
/tjj̀k/
'person'
'neck'.

Gloss 
Unubi, Sunday Abraham; Consonant Deletion in the Speech of English-Platoid Bilinguals, Advances in Image and Video Processing, Volume 7 No 1, February (2019); pp: 19-33

\section{Berom Consonant Sounds \& Some Lexical items}

\begin{tabular}{|c|c|c|c|c|c|c|c|}
\hline $\begin{array}{l}\text { Place } \rightarrow \\
\text { Manner } \downarrow\end{array}$ & Bilabial & $\begin{array}{l}\text { Labio- } \\
\text { dental }\end{array}$ & Alveolar & $\begin{array}{l}\text { Palato- } \\
\text { alveolar }\end{array}$ & Palatal & Velar & Glotal \\
\hline Plosive & $\begin{array}{l}p \\
b\end{array}$ & & $\begin{array}{l}t \\
d\end{array}$ & & & $\begin{array}{l}\mathrm{k} \\
\mathrm{g}\end{array}$ & \\
\hline Fricative & & $\begin{array}{l}f \\
v\end{array}$ & 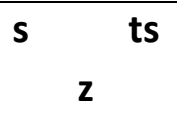 & $\int$ & & & h \\
\hline Affricate & & & & $\begin{array}{l}\text { t } \\
d 3\end{array}$ & & & \\
\hline Lateral & & & I & & & & \\
\hline Trill & & & $r$ & & & & \\
\hline Approximant & $\mathbf{w}$ & & & & $\mathbf{j}$ & & \\
\hline Nasal & m & & $\mathbf{n}$ & & & n & \\
\hline
\end{tabular}

Word
(a) Ǹshí
/ìjíl
'water'
(b) Lóh/ló/
'house'
(c) Hwóng
/hwón/
'girl'
(d) Ndém
/ndém/
'law enforcement agent'
(e) Vú
/vú/
'dog'
(f) Pyénrè /pjénrè/ 'food'.

4. Piapung Consonant Sounds \& Some Lexical items

\begin{tabular}{|c|c|c|c|c|c|c|}
\hline $\begin{array}{l}\text { Place } \rightarrow \\
\text { Manner } \downarrow\end{array}$ & Bilabial & $\begin{array}{l}\text { Labio- } \\
\text { Dental }\end{array}$ & Alveolar & Palatal & Velar & Glottal \\
\hline Plosive & $\mathbf{p} \quad \mathbf{b}$ & t $\quad d$ & $d 3$ & & k $\quad$ g & \\
\hline Implosive & b & d & & & & \\
\hline Fricative & & $\begin{array}{ll} & v \\
\end{array}$ & S $\quad$ z & J 3 & & $h$ \\
\hline Nasal & $m$ & $n$ & & & $\eta$ & \\
\hline Liquid & & $I$ & & $r$ & & \\
\hline Semi-vowel & & & & $y$ & & $\mathbf{w}$ \\
\hline
\end{tabular}


Word
(a) Kyang
/kján/
'hoe'
(b) Ham
/hàm/
'water'
(c) Shim / /ím/
'yam
(d) Shẹrẹp / /
'fish'
(e) Kong
/kכ̄y/
'river'
(f) Tẹng
$/ \mathrm{t \varepsilon g} /$
'tree'.

\section{Kulere}

Word

(a) Àm/àm/ ' 'water'

(b) Riek

/riēk/

(c) Rìyau

/rìjav/

(d) Taná

/tæná/

(e) Lush

/Lūg/

/giau/

(f) girau

\section{Iguta}

\section{Word}

\section{Gloss}
(a) Mini
/mInI/
'water'
(b) Rizhì
/rizì/
'eye'
(c) Worí
/wərí/
'hand'
(d) Bìmu
/bìmū/
'nose'
(e) Rəlem /rəlēm/
'tongue
(f) Anyíyí
'teeth'.

\section{Ron}

Word

Gloss 

(a) Kámbơng
/kámbon/
'cocoyam'
(b) Challà
/ţəlà/
'peace'
(c) Dán'máfwàshì /dánmáfwà`ı/ 'snake'
(d) Bakam
/bākām/ 'knife'
(e) Rawúl
/rowúl/
'potatoes'
(f) Ligit
/līgīt/
'drinks'.

\section{Afizere}

Word

Gloss

(a) İshọsh /îJ]/ 'bee'

(b) İnyám /înám/ 'antelope'

(c) Àgàbú /àgàbú/ 'dog'

(d) Nànámàng /nànámàn/ 'girls'

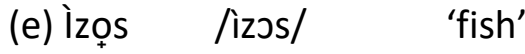

(f) Kùrớng /kùrón/ 'fire'.

\section{Mupun}

Word

Gloss

$\begin{array}{llll}\text { (a) } & \text { Fwan } & / \text { wwan/ }^{w} & \text { 'rain' } \\ \text { (b) } & \text { Kam } & / \mathrm{kam} / & \text { 'stick' } \\ \text { (c) } & \text { Pel } & / \mathrm{pcl} / & \text { 'leaves' } \\ \text { (d) } & \text { Wur } & \text { /wur/ } & \text { 'breast' } \\ \text { (e) } & \text { Fwat } & / \mathrm{f}^{\mathrm{w}} \text { uat/ } & \text { 'ashes' } \\ \text { (f) } & \text { Amkur } & \text { /amku:r/ } & \text { 'sea'. }\end{array}$

As we carefully consider the data from the ten indigenous Platoid languages above, one thing that can be observed easily is the fact that their words do have a cluster of consonants at word-initial positions but do not at word-final positions. Even in Ngas language (number three) where we would have considered the word Gùrm 'person' as an exception, we discover that in actual realisation or articulation, a schwa vowel is inserted between the two consonants at the word-final position. In fact, 
the schwa is neither weak nor silent but sonorous to the extent that it receives a tone-mark according to its transcription: /gùràm/.

In addition, it is not out of place to say that since consonant cluster exists word initially in Platoid languages, English-Platoid bilinguals do not delete consonants in English words with a cluster of consonants word initially. Evidence of this is clearly seen in our data presentation, and some of the

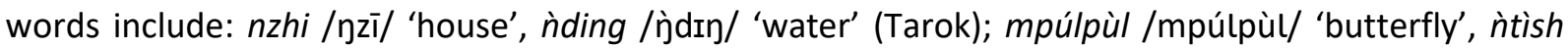

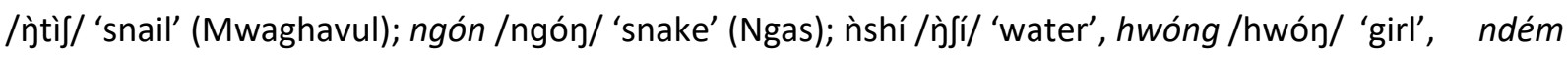
/ndém/ 'law enforcement agent', pyénrè /pjénrè/ 'food' (Berom); kyang/kján/ 'hoe' (Piapung); and fwan /fwuan/ 'rain', fwat /fwuat/ 'ashes' (Mupun).

Similarly, according to the data, Platoid languages also have consonant cluster word medially, as seen in words such as iyamrì /ījamrì/ 'food' (Tarok); làngtíng /làntín/ 'witness', shikbish /Jikbîj/ 'sin', mpúlpùl /mpúlpùl/ 'butterfly', Naanfwang /nāānfwān/ 'God guides' (Mwaghavul); pyénrè /pjénrè/ 'food' (Berom); kámbọn /kámbon/ 'cocoyam', challà /ţəlà/ 'peace', dán'máfwàshì /dánmáfwàji/ 'snake' (Ron); and amkur /amku:r/ 'sea' (Mupun). Consequent upon this, it is also not out of place to suggest that consonants in English words that are clustered word medially do not get deleted by English-Platoid bilinguals.

Furthermore, as viewed from the data, it is true as well that the orthographic -ng which gives birth to the phonetic velar nasal $/ \mathrm{h} /$, which usually occurs word medially and finally in English also operates equally in Platoid languages, as in ǹding / ̀̀dın/ 'water', ìkpáng /ìkpán/ 'plate' (Tarok); làngtíng /làntín/ 'witness' (here it appears both medially and finally), Naanfwang /nāānfwān/ 'God guides'

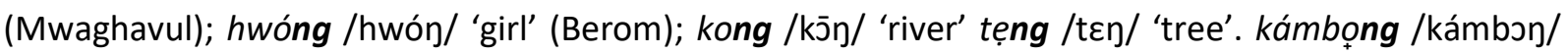
'cocoyam' (Ron); and nànámàng /nànámàn/ 'girls', kùrọng /kùrón/ 'fire' (Afizere). Since the dentalnasal $n$ and the velar-plosive $g$ constitute a digraph, deleting it word finally is practically impossible. Consequently, English-Platoid bilinguals maintain and articulate the sound correctly in English words that contain it both at medial and final positions.

\subsection{Research Findings}

Considering the data presentation and analysis above, the following are the findings of this study: (i) English-Platoid bilinguals delete the last consonant in a cluster of consonants due to the fact that consonant cluster does not exist word finally in Platoid languages; (ii) the word gùrm 'person' in Ngas appears to be diametrically opposed to (i) above when viewed orthographically but when viewed phonetically - gùrm /gùràm/, it is in tandem. This is because in actual realisation, a schwa vowel is inserted between the two consonants at word final position, and the schwa becomes sonorous to the

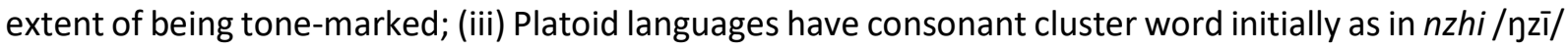
'house' (Tarok), mpúlpùl /mpúlpùl/ 'butterfly', (Mwaghavul), ngón /ngón/ 'snake' (Ngas), ndém /ndém/ 'law enforcement agent' (Berom), kyang /kján/ 'hoe' (Piapung), etc. and as such, EnglishPlatoid bilinguals do not delete any consonant in English words containing a consonant cluster word initially; (iv) Platoid languages also have consonant cluster word medially as observed in these words iyamrì /ījamrì/ 'food' (Tarok), Naanfwang /nāānfwān/ 'God guides' (Mwaghavul), pyénrè /pjénrè/ 'food' (Berom), kámbọn /kámbon/ 'cocoyam' (Ron), amkur /amku:r/ 'sea' (Mupun), etc. and for this reason, consonant deletion by English-Platoid bilinguals does not take place in English words having a cluster of consonants at the medial position; ( $v$ ) the orthographic -ng which gives birth to the phonetic velar nasal $/ \mathrm{h} /$, and which usually occurs word medially and finally in English is a very common occurrence in many words of Platoid languages such as nànámàng /nànámàn/ 'girls', kùrớng /kùrón/ 'fire' (Afizere); hwóng /hwón/ 'girl' (Berom); làngtíng /làntín/ 'witness', Naanfwang /nāānfwān/ 'God 
Unubi, Sunday Abraham; Consonant Deletion in the Speech of English-Platoid Bilinguals, Advances in Image and Video Processing, Volume 7 No 1, February (2019); pp: 19-33

guides' (Mwaghavul); kong /k̄̄y/ 'river' tẹng /tø̣/ 'tree', kámbơng /kámbon/ 'cocoyam' (Ron); ǹding /j̀dın/ 'water', ikpáng /ìkpán/ 'plate' (Tarok); etc. - making it difficult for English-Platoid bilinguals to delete either the dental-nasal $n$ or the velar plosive $g$ in English words that contain them both at the medial and final positions because they form a digraph.

\section{Contribution to Knowledge}

Certainly, this research has contributed in no small measure to knowledge as far as the field of Language \& Linguistics is concerned. Generally, making this kind of research available in language study as an addition to the existing body of knowledge in which it serves as a reference material for laymen, language enthusiasts as well as students and scholars in general linguistics globally is actually a good contribution. Specifically, our presentation of data and analysis of both data (A \& B) have exposed to the readership the reason why English-Platoid bilinguals delete the last consonant in a cluster of consonants, and that is, no consonant cluster word finally in Platoid languages. Furthermore, the insertion of a schwa in the Ngas word gùrm /gùràm/ 'person' has given credibility to this claim. Consequently, the effect or influence of this is brought to bear on the English-Platoid bilinguals' use of the English language, which is popularly referred to as mother-tongue interference under teaching and learning situation. Besides, this study seems to be a pioneer, and as such, it is definitely expected to produce chain reactions because it will surely provoke more researches in this area of linguistic study, not just in Nigeria and Africa alone but also the rest of the world.

\section{Conclusion}

This paper, in its best attempt has examined consonant deletion in the speech of English-Platoid bilinguals. From the data gathered, presented and analysed, it revealed that Platoid languages do have evidence of consonant cluster at word-initial and medial positions but do not at word final position. Therefore, we validly conclude that English-Platoid bilinguals do delete consonants at word final position in English words containing them (consonants) due to the fact that consonant cluster does not exist word finally in Platoid languages. As a result, English-Platoid bilinguals have transferred this phenomenon into the English language, a situation which is regarded as mother-tongue interference in language teaching and learning. Also, it is worthy of mention to point out here that where a cluster of consonant appears to be present orthographically, it only exists as a digraph, as in ishosh 'honey bee', nànámàng 'girls' (Afizere); hwóng /hwón/ 'girl' (Berom); làngtíng /làntín/ 'witness', Naanfwang /nāānfwān/ 'God guides' (Mwaghavul); kong /kōy/ 'river' tẹng /tøı/ 'tree', kámbơng /kámbon/ 'cocoyam' (Ron); ìding /ìdın/ 'water', ikpáng/ikpán/ 'plate' (Tarok); etc.

\section{REFERENCES}

[1] Adomako, K. 2008. Vowel epenthesis and consonant deletion in loanwords: A study of Akan. MA Thesis. University of Troms $\varnothing$ [Online] Available: https://core.ac.uk/download/pdf/19637203.pdf. 5/8/2018.

[2] Alabi, T. 2017. A brief history of Plateau State. Information Nigeria Newspaper of $4^{\text {th }}$ March, 2017. [Online] Available: http://www.informationng.com/2017/03/brief-history-plateau-state.html. 3/7/2018.

[3] Amenorvi, C.R. 2011. A comparative study of cohesion in English and Ewe: A case study of some written texts. M.A Dissertation. University of Cape Coast. [Online] Available: https://ucc.edu.gh/. 4/7/2018. 
[4] Blench, R. 2008. Prospecting Proto- Plateau. Kay Williamson Educational Foundation. Cambridge, United Kingdom.

[5] Crystal, D. 1991. A dictionary of linguistics and phonetics. Oxford: Blackwell Publishers.

[6] Davidson, L. 2004. Schwa elision in fast speech: Segmental deletion or gestural overlap? New York University, Department of Linguistics. [Online] Available: https://wp.nyu.edu/lisa davidson/wp-content/uploads. 4/72018.

[7] Franson, C. 2011. What is bilingualism? [Online] Available: https://www.naldic.org.uk/Resources/NALDIC. 5/8/2018.

[8] Gerlach, S.R. 2010. The acquisition of consonant feature sequences: Harmony, metathesis and deletion patterns in phonological development. PhD Dissertation. University of Minnesota. [Online] Available: https://conservancy.umn.edu/bitstream/handle/11299/99807/1/Gerlach umn 0130E 117 05.pdf. 4/7/2018.

[9] Jones, D. 2003. English pronouncing dictionary. Roach, Hartman \& Setter (eds). Cambridge University Press.

[10] Liddicoat, A. 1991. Bilingualism: An introduction. Educational Resources Information Centre (ERIC).

[11] Love, N. (1986). The linguistic thought of J. R. Firth. Stellenbosch Papers in Linguistics. 15, 31 - 60. [Online] Available: file:///C:/Users/user/Downloads/116505-323575-1-SM.pdf. $\underline{4 / 7 / 2018 .}$

[12] Ogbulogo, C. 2013. Language engineering and the destiny of man in Africa. Covenant University $3^{\text {rd }}$ Inaugural Lecture, Covenant University.

[13] Ovu, B.F. 2013. Consonant deletion in English: Phonotactic explications and implications for teaching spelling in an ESL situation. Journal of School of Languages. Ebonyi State College of Education, South-Eastern Nigeria. 1, 79-87.

[14] Rashidi, N. and Shokrollahi, M. 2010. Elision of /h/ and /?/ in the Shirazi dialect of Persian (SHDP): An optimality theory based analysis. Shiraz University, Iran. [Online] Available: file://C:/Users/user/Downloads/36 107 RASHIDI 04.pdf. 5/8/2018.

[15] Rippon, H. 2017. Minimal pairs' consonant deletion. $2^{\text {nd }}$ (ed.). Black Sheep Press.

[16] Williamson, K. The pedigree of nation: Historical linguistics in Nigeria. $5^{\text {th }}$ Inaugural Lecture, University of Port Harcourt, Port Harcourt. 